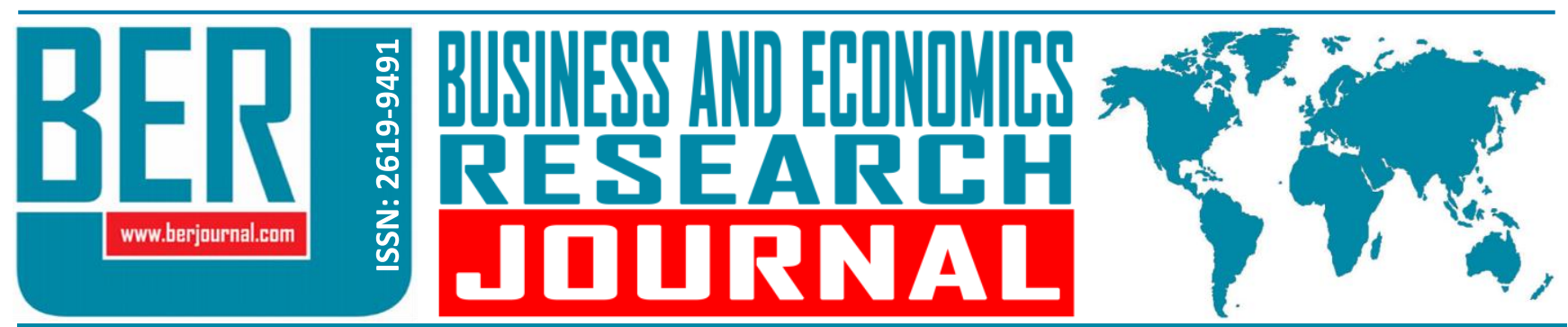

Business and Economics Research Journal Vol. 11, No. 2, 2020, pp. 581-590 doi: 10.20409/berj.2020.269

\section{Yönetim ve Örgütsel Davranış Yazınındaki Ölçek Geliştirme Çalışmalarının Metodolojik Açıdan Analizi}

\author{
Pelin Kanten ${ }^{\mathrm{a}}$, Benan Arda ${ }^{\mathrm{b}}$
}

Öz: Ölçek geliş̧tirme, önemli uzmanlık bilgisini ve uzun süren çabayı gerektiren bir çalışmadır. Bu çalışmaların bilimsel açıdan geçerli ve güvenilir olması belirli metodolojik ilkelerin uygulanmasını gerekli kılmaktadır. Sosyal bilimler yazınındaki mevcut ölçek geliştirme çalışmalarının bir kısmında belirli yöntemlerin uygulandığı, bazılarında ise bilimsel kriterlerin her aşamasının dikkate alınmadığı görülmektedir. Bu çerçevede, çalışmada 2000-2019 yılları arasında yönetim ve örgütsel davranış yazınındaki ölçek geliştirme çalışmaları içerik analiz yöntemi ile metodolojik açıdan incelenmiştir. Araştırma amacı kapsamında belirtilen yıllarda ulusal veri tabanlarında taranan 65 adet lisansüstü tez, makale ve bildiri incelenerek, ölçek geliştirme adımları çerçevesinde uygulanan yöntemlerin belirlenmesi ve uygulanması gereken aşamaların bir model dâhilinde sunulması amaçlanmıştır. Bu bağlamda, yönetim ve örgütsel davranış yazınındaki 65 ölçek geliştirme çalışması belirlenen ölçek geliştirme kriterleri kapsamında MAXQDA nitel veri analizi programı kullanılarak değerlendirilmiştir.

\section{The Methodological Analysis of Scale Development Studies in Management and Organizational Behavior Fields}

Abstract: Scale development is a study that requires significant expert knowledge and long-term effort. The scientificness of these studies in terms of reliability and validity is based on the implementation of some methodological principles. In the social sciences literature, it is seen that specific methods are applied in some of the scale development studies, while in others, every stage of the scientific criteria is not taken into account. In this context, this study aimed to examine the scale development studies in management and organizational behavior literature between the 2000-2019 years from the methodological perspective by the content analysis. As the scope of the objectives of the study, it is aimed to determine the existing methods of the scale development process in the studies and to present a model that includes the required steps of the scale development studies. According to this purpose, 65 studies in the scope of the graduate theses, articles, and conference proceedings indexed by the national database in Turkey between the specific years are examined. These 65 studies are evaluated using the qualitative data analysis program MAXQDA 10.0 software based on scale development criteria determined.
Anahtar Sözcükler: Ölçek Geliştirme, Metodoloji, Yönetim, Örgütsel Davranış

JEL: M10, M20

$\begin{array}{ll}\text { Geliş } & : 29 \text { Ocak } 2020 \\ \text { Düzeltme } & : \text { 20 Mart 2020 } \\ \text { Kabul } & : \text { 30 Mart 2020 } \\ \text { Tür } & : \text { Araştırma }\end{array}$

Keywords: Scale Development, Methodology, Management, Organizational Behavior

JEL: M10, M20

a Assoc. Prof., PhD., Canakkale Onsekiz Mart University, Faculty of Political Sciences, Department of Business Administration, Canakkale, Turkiye, pelinkanten@comu.edu.tr (ORCID ID: 0000-0002-6487-0203)

b PhD. Student, Canakkale Onsekiz Mart University, Faculty of Political Sciences, Department of International Business, Canakkale, Turkiye, benanciplak@gmail.com (ORCID ID: 0000-0001-7530-5966) 


\section{Giriş}

Sosyal bilim araştırmalarında bireylerin özelliklerini, yeteneklerini, algılama düzeylerini, tutum ve davranış eğilimlerini ölçmek amacıyla ölçek olarak adlandırılan veri toplama araçlarından yararlanılmaktadır (Uyanık vd., 2017: 184). Ölçek, sosyal bilimler alanında bireylere, karşılaşılan durumlara, süreçlere ve nesnelere ilişkin bilgi elde etmeyi sağlayan işlevsel bir araçtır (Morgado vd., 2015: 1). Bu araçlar, bireyler arasındaki farklılıkları ve aynı bireylerin değişik durumlar karşısında gösterdikleri tepkiler arasındaki farklılıkları ortaya çıkarmak amacıyla kullanılmaktadır (Yurdabakan ve Çüm, 2017: 110). Dolayısıyla, ölçeklerin sosyal bilimlerde doğrudan gözlemlenemeyen, soyut yapıların sayısal hale getirilerek ölçülmesini kolaylaştırmaktadır (Bolarinwa, 2019: 195). Literatürde; sosyal bilim araştırmacılarının var olan ölçekleri kullandıkları veya mevcut ölçeklerin işlevsel olmadığını düşünerek, ölçek oluşturmaya çalıştıkları görülmektedir. Mevcut ölçeklerin yetersiz olduğuna ise ölçülmek istenen değişken ve bu değişken ile ilişkili yapının açık olarak tanımlanmasıyla karar verilmesi gerekmektedir. Başka bir ifadeyle, öncelikle ölçülmek istenen değişken ile ilgili mevcut ölçeğin varlığı sorgulanarak, bu ölçeğin söz konusu değişkeni ölçme yeterliliği analiz edilmelidir. Bununla birlikte var olan ölçeğin uyarlanmasının veya yeni bir ölçek geliştirmenin hangisinin daha anlamlı olduğunun irdelenmesi önem taşımaktadır (Şahin ve Öztürk, 2018: 191). Özellikle psikoloji, tutum ve davranış gibi alanlarda çalışan araştırmacıların mevcut ölçeklerin bazı eksikliklerinin olması sebebiyle genellikle ölçek geliştirme eğilimi içerisinde olduğu görülmektedir. Ancak araştırmacılar, son yıllarda ölçek geliştirmenin araştırma tasarımı ve yürütülmesini kapsayan nicel ve nitel gibi karma metodolojik yöntemlerin uygulanmasını gerektiren sistematik bir süreç olduğunun farkındadır (Zhou, 2019: 38). Dolayısıyla, ölçek geliştirme çalışmaları belirli ilkelerin adım adım izlenmesini zorunlu kılan, uzun soluklu ve zahmetli bir süreçtir. Ulusal ve uluslararası yazındaki ölçek geliştirme çalışmaları incelendiğinde, birçok çalışmada ölçek geliştirme adımlarının bütünüyle uygulanmadığı, bazı istatistiki tekniklerin göz ardı edildiği, yüzeysel düzeyde ölçeklerin geliştirildiği ve metodolojik açıdan eksiklikler olduğu görülmektedir. Bu bağlamda, çalışmada ulusal yazında yönetim ve örgütsel davranış alanındaki ölçek geliştirme çalışmalarının ölçek geliştirme adımları çerçevesinde irdelenmesi ve elde edilen sonuçlar kapsamında uygulanması gereken aşamaların bir model içerisinde sunulması amaçlanmaktadır.

\section{Kavramsal Çerçeve}

Ölçek, sosyal bilimlerde ölçmeye konu olan bir özelliğin sınıflanmasında, sıralanmasında ve ölçmek istenen değişkenin miktar ve düzeyinin belirlenmesinde kullanılan ölçme aracı olarak tanımlanmaktadır (Karakoç ve Dönmez, 2014: 40). Ölçek, doğrudan gözlemlenemeyen örtük değişkenlerin bir takım somut ifadelerle elde edilme çabasını nitelemektedir. Başka bir ifadeyle, ölçek doğrudan anlamlandırılamayan teorik değişkenlerin açığa çıkarılmasını kolaylaştıran bütünleşik maddelerden oluşmaktadır (Carpenter, 2019: 2627). Ölçek geliştirme ise, ölçülmek istenen yapıyı ölçmesi mümkün olan geçerli ve güvenilir ölçek meydana getirme sürecidir. Ölçek geliştirmenin temeli tümdengelim ve tümevarım olmak üzere iki farklı yaklaşıma dayanmaktadır. Tümdengelim, belirli bir kuramsal teoriden yola çıkarak, değişkenin kavramsallaştırılması ve bu değişkene ilişkin madde oluşturma süreci iken tümevarım yaklaşımı ise ölçülecek değişkenin kavramsallaştırılmasında ve boyutlarının tanımlanmasında mülakat, gözlem ve bireysel tepkiler gibi unsurların dikkate alınmasını ifade etmektedir (Tay ve Jebb, 2017: 2). Literatürde ölçek geliştirme sürecinde tümdengelim ve tümevarım yaklaşımlarının bir arada kullanılmasının ölçülmek istenen değişkenin tanımlanmasında ve ölçebilecek maddelerin oluşturulmasında en iyi uygulama olduğu ileri sürülmektedir (Boateng vd., 2018: 149). Ancak bu yaklaşımlar ile birlikte bir ölçek geliştirme çalışmasının bilimsel olarak kabul edilebilmesi, ölçüm aracının geliştirilmesinde belirli standartlara uyulmasını zorunlu kılmaktadır. Dolayısıyla, ölçek geliştirme çalışmalarında, ölçülmek istenen değişkenin tanımlanması ve bu değişkenin kuramsal dayanağının belirlenmesiyle birlikte mevcut araştırmalardan yola çıkarak, kavrama ilişkin bilgiler toplanması ve ölçme konusunda metodoloji bilgisine sahip olunması önem taşımaktadır (Yurdabakan ve Çüm, 2017: 10).

Ölçek geliştirme veya var olan bir ölçeği uyarlama derin bir uzmanlık gerektiren bir süreçtir. Başka bir ifadeyle, ölçülmek istenen değişkene ilişkin madde havuzu herhangi bir yaklaşımı dikkate almadan, rastgele araştırmacı tarafından yazılan sorulardan ibaret değildir. Özellikle güvenilir ve geçerli bir ölçek geliştirme 
süreci, belirli adımların ve çeşitli istatistiksel metotların uygulanmasını gerektirmektedir (Çüm ve Koç, 2013: 117). Bu aşamalar DeVellis (2003) tarafından sekiz basamaklı bir süreç olarak özetlenmektedir. Birinci basamak, ölçmek istenen değişkenin kavramsal ve kuramsal çerçevesinin çizilmesi, ikinci basamak belirli yaklaşımlar temelinde madde havuzunun oluşturulması, üçüncü basamak ölçme yönteminin belirlenmesi, dördüncü basamak başlangıç madde havuzunun uzmanlar tarafından değerlendirilmesi, beşinci basamak pilot araştırma, altıncı basamak güvenilirlik analizleri, yedinci basamak geçerlilik analizleri, sekizinci basamak ölçeğe nihai halinin verilmesidir. Bu basamakları aşağıdaki şekildeki gibi özetlemek mümkündür:

\section{1. Ölçüm Değişkenin Belirlenmesi}

- Kavramın Tanımı

- Kuramsal Dayanağı

- Alandaki mevcut ölçeklerin sorgulanması

2. Madde Havuzu Oluşturma

- Tümevarım (İçerik analizi, mülakat, odak grup)

- Tümdengelim (Literatür taraması, mevcut ölçekler)

3. Başlangıç madde havuzunun uzman değerlendirmesi (Odak grup)

- İçerik Geçerliliği (KGI)

- Görünüm Geçerliliği

4. Uygun olmayan maddelerin elenmesi

5. Ölçüm Formatının Belirlenmesi (5'li / 7'li Likert)

6. Pilot Uygulama (Faktör ve Güvenilirlik Analizleri)

7. Geçerli maddelerin ölçeğe dahil edilmesi

8. Nihai uygulama

9. Ölçek Geliştirmede Kullanılan Tekniklerin Belirlenmesi

- Klasik Test Kuramı (Maddeler arası korelasyon)

- Madde Tepki Kuramı (Madde ölçek toplam puanı ile maddeler arası korelasyon)

- Faktör Analizi

- Yapısal Eşitlik Modeli

10. Güvenilirlik Analizleri

- Madde toplam korelasyon (0,50'nin üzerinde olması, negatif işaret olmaması)

- Test-tekrar (1.aşama ile 2.aşama korelasyon değerlerinin karşılaştırılması (>0,70 olmalı

- Paralel-form (Ana form ile paralel form madde boyutlarının korelasyonları)

- iç Tutarlılık katsayısının hesaplanması (>0,70 olmalı)

- Birleşik güvenilirlik ((>0,70 olmalı) ve AVE değerlerinin (>0,50 olmalı) hesaplanması

- Yarıya Bölme yöntemi

11.Geçerlilik Analizleri

- İçerik Geçerliliği (Uzman görüşleriyle, her maddenin gerekli/gereksiz şeklinde puanlanarak, kapsam geçerlilik değerinin hesaplanması) 
- Yapı Geçerliliği

a) Benzeşim Geçerliliği (Cronbacha's Alpha, CR ve AVE değerlerinin hesaplanması)

b) Ayrışım Geçerliliği (Boyutlarası korelasyon ve Fornell Lorcker Kriterinin hesaplanması)

c) Açıklayıcı Faktör Analizi

d) Doğrulayıcı Faktör Analizi

\section{- Ö̈lçüt-Bağımlı Geçerliliği (Uyum geçerliliği- Eş zaman geçerliliği)}

Literatürde mevcut ölçek geliştirme çalışmaları incelendiğinde bazılarında yukarıda söz edilen bu adımların tamamen uygulandığı, bazılarında kısmen gerçekleştirildiği ve metodolojik eksikliklerin olduğu görülmektedir. Bu eksiklikleri ele alan ulusal yazındaki ölçek geliştirme çalışmalarında; Çüm ve Koç (2013), Dirlik (2014), Tavşancıl vd. (2014), Uyanık vd. (2017), Şahin ve Öztürk (2018) ve Yeşilyurt ve Çapraz (2018) ölçek geliştirme sürecinde adımlar eleştirel bir bakış açısıyla incelenmiştir. Bu çalışmalar incelendiğinde ölçek geliştirme çalışmalarındaki metodolojik eksikliklere değinildiği ancak ölçek geliştirme sürecinde izlenmesi gereken adımların detaylı olarak verilmediği görülmektedir. Dolayısıyla bu çalışmada, 2000-2019 yılları arasında Türkiye' deki ulusal veri tabanlarında taranan dergiler ile YÖK tez merkezine kayıtlı lisansüstü tezler ve ulusal bildiri kitaplarında yer alan 65 adet ölçek geliştirme çalışmasının metodolojik açıdan irdelenmesi amaçlanmaktadır. Bu çerçevede, mevcut tarihler arasındaki ölçek geliştirme çalışmaları DeVellis (2003), Cabrera-Nguyen (2010), Boateng vd. (2018) ve Carpenter (2018) tarafından ele alınan ölçek geliştirme adımları kapsamında içerik analizi yöntemiyle incelenmiş ve aşağıdaki sorulara cevap aranmıştır:

(1) Ölçek geliştirme çalışmalarında ölçüm değişkeninin kuramsal temeli ve kavramın tanımı açıkça belirtilmiş midir?

(2) Ölçek geliştirme çalışmalarında madde havuzu nasıl oluşturulmuştur?

(3) Ölçek geliştirme çalışmalarında ölçme yöntemi belirtilmiş midir?

(4) Ölçek geliştirme çalışmalarında başlangıç madde havuzu uzman görüşüyle değerlendirilmiş midir?

(5) Ölçek geliştirme çalışmalarında pilot araştırma yapılmış mıdır?

(6) Ölçek geliştirme çalışmalarında pilot araştırma sonrasında uzman görüşleriyle madde azaltma yapılmış mıdır?

(7) Ölçek geliştirme çalışmalarında hangi ölçek geliştirme teorileri temel alınmıştır?

(8) Ölçek geliştirme çalışmalarında nihai uygulama sonrasında güvenilirlik analizleri kapsamında hangi testler uygulanmıştır?

(9) Ölçek geliştirme çalışmalarında nihai uygulama sonrasında geçerlilik analizleri kapsamında hangi testler uygulanmıştır?

(10) Ölçek geliştirme çalışmalarında ölçek uygun hale getirildikten sonra çalışma kapsamında ölçek maddeleri verilmiş midir?

\section{Araştırmanın Amacı ve Yöntemi}

Araştırmanın amacl; Türkiye'de yönetim organizasyon ve örgütsel davranış yazınında yayınlanan ölçek geliştirme çalışmalarının içerik analizi yöntemi kullanılarak metodolojik açıdan incelenmesidir. Yönetim yazını kapsamında insan kaynakları yönetimi ve stratejik yönetim alanındaki çalışmalar araştırma kapsamına dâhil edilmiştir. Bu amaç kapsamında Türkiye'de ulusal veri tabanlarında 2000-2019 yılları arasında yönetimorganizasyon ve örgütsel davranış yazınında tez, bildiri ve makale türleri altında yer alan 65 adet bilimsel çalışma yukarıda belirtilen araştırma sorularına cevap aranarak, nitel araştırma desenlerinden betimleyici analiz vasıtasıyla irdelenmiştir. İçerik analizinin ilk basamağı olan betimsel analiz, elde edilen verilerin belirlenen temalar çerçevesinde özetlenmesini kapsamaktadır (Sığrı, 2018: 276). Bu doğrultuda, belirtilen 
tarih aralığında ulusal veri tabanlarında yer alan ölçek geliştirme çalışmaları taranarak; açık kodlama, eksen kodlama (kategorileştirme), seçici kodlama (temalaştırma), kategori azaltma ve model önerisi geliştirme olmak üzere dört aşamada incelenmiştir (Kanten vd., 2018: 945). Bununla birlikte, araştırmanın güvenirliği ise alanında deneyimli bir akademisyene kategorilendirme işlemi yaptırılarak, elde edilen kategoriler ile araştırmacıların oluşturduğu kategorilerin karşılaştırılması ile sağlanmıştır. Belirlenen araştırma amacı çerçevesinde, var olan kayıt ve belgeler amaçlı örnekleme yöntemlerinden ölçüt örnekleme tekniği kullanılarak taranmıştır. Araştırmacılar tarafından 2000-2019 yılları arasında ulusal düzeyde yayınlanan yönetim ve örgütsel davranış alanındaki ölçek geliştirme konulu çalışmalar ölçüt olarak belirlenmiştir. Bu ölçütler doğrultusunda, makalelere erişilmesinde Türkiye'de ULAKBIM, ASOS ve SOBIAD tarafından taranan bilimsel hakemli dergiler irdelenmiş, tezler için YÖK veri tabanından yararlanılmıştır. Ulusal düzeydeki bildirilere erişilmesinde ise Türkiye'de düzenlenen alanının önde gelen kongreleri içerisinde yer alan yönetim ve organizasyon ile örgütsel davranış kongrelerinin bildiri kitapları dikkate alınmıştır. Ölçüt olarak belirlenen kriterler çerçevesinde tüm kaynaklara erişilmesinde anahtar kelime olarak "ölçek geliştirme" belirlenmiş, bu anahtar kelime ile sıralanan kaynaklar içerisinden yönetim-organizasyon ve örgütsel davranış yazınını kapsayan çalışmalar seçilmiş ve araştırma kapsamına dâhil edilmiştir. Bu kısıtlar çerçevesinde araştırmanın veri kaynağı olan 65 adet ölçek geliştirme çalışmasının yıllar itibariyle dağılımı Tablo 1'de verilmektedir.

Tablo 1. 2000-2019 Yılları Arasındaki Ulusal Düzeyde Yayınlanan Ölçek Geliştirme Çalışmalarının Dağılımı

\begin{tabular}{|c|c|}
\hline Yıllar & Sayı \\
\hline 2000 & - \\
\hline 2001 & - \\
\hline 2002 & 1 \\
\hline 2003 & - \\
\hline 2004 & 1 \\
\hline 2005 & - \\
\hline 2006 & 1 \\
\hline 2007 & 2 \\
\hline 2008 & - \\
\hline 2009 & 9 \\
\hline 2010 & 1 \\
\hline 2011 & 3 \\
\hline 2012 & 5 \\
\hline 2013 & 8 \\
\hline 2014 & 9 \\
\hline 2015 & 7 \\
\hline 2016 & 5 \\
\hline 2017 & 6 \\
\hline 2018 & 7 \\
\hline 2019 & - \\
\hline Toplam & 65 \\
\hline
\end{tabular}

\section{Araştırma Bulguları}

Araştırmada incelenen ulusal düzeydeki bilimsel nitelikli yayınlar (lisansüstü tezler, makale, bildiri) belirlenen ölçütlere göre kodlanmıştır. Kodlar arasındaki ilişkilerin oluşturduğu yapı içerisinde 9 adet kategori (ölçüm değişkenin belirlenmesi, madde havuzunun oluşturulması, madde havuzunun değerlendirilmesi, ölçme yöntemi, pilot uygulama, pilot araştırma sonrası uzman değerlendirmesi, güvenilirlik analizleri, geçerlilik analizleri, nihai ölçek maddelerinin belirlenmesi) olmak üzere 924 açık kod belirlenmiştir. Bu kodların görselleştirilmesinde frekans (f) tablo ve grafikleri, yoğunluk tabloları ve kod haritaları kullanılmıştır. 


\section{1. Ölçek Geliştirme Çalışmalarının Bilim Alanı Olarak Dağılımına İlişkin Bulgular}

Araştırma kapsamında öncelikle konunun ana başlı̆ını ifade eden yönetim ve örgütsel davranış yazınındaki ölçek geliştirme çalışmalarının bilim alanı olarak dağılımı belirlenmeye çalışılmıştır. Şekil 1'de 2000-2019 yılları arasında YÖK tez merkezinde ve ulusal veri tabanlarında taranan yönetim ve örgütsel davranış yazınındaki ölçek geliştirme çalışmalarının yüzdesel dağııımı verilmektedir.

Şekil 1. 2000-2019 Yılları Arasındaki Ölçek Geliştirme Çalışmalarının Bilim Alanlarına Göre Yüzdesel Dağılımı

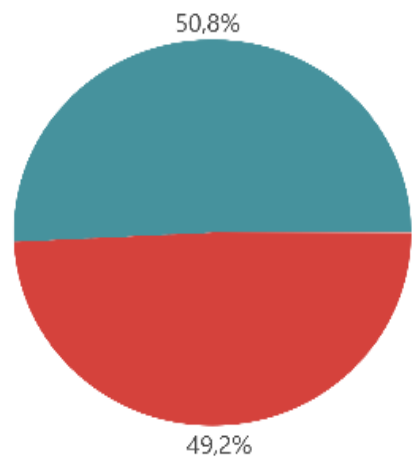

Buna göre, belirtilen yıllarda yönetim ve örgütsel davranış alanındaki ölçek geliştirme çalışmalarının $(\% 50,8)$ yönetim ve $(\% 49,2)$ ile ise örgütsel davranış alanında olduğu görülmüştür. Dolayısıyla, ölçek geliştirme çalışmalarının bilim alanı dağılımı açısından birbirine oldukça yakın düzeyde olduğu ifade edilebilir.

\section{2. Ölçek Geliştirme Çalışmalarının Yayın Niteliğine Göre Dağılımına iliş̧kin Bulgular}

Şekil 2'de 2000-2019 yılları arasında YÖK tez merkezinde ve ulusal veri tabanlarında taranan yönetim ve örgütsel davranış yazınındaki ölçek geliştirme çalışmalarının yayın türüne göre yüzdesel dağıımı verilmektedir.

Şekil 2. 2000-2019 Yılları Arasındaki Ölçek Geliştirme Çalışmalarının Yayın Niteliğine Göre Yüzdesel Dağılımı

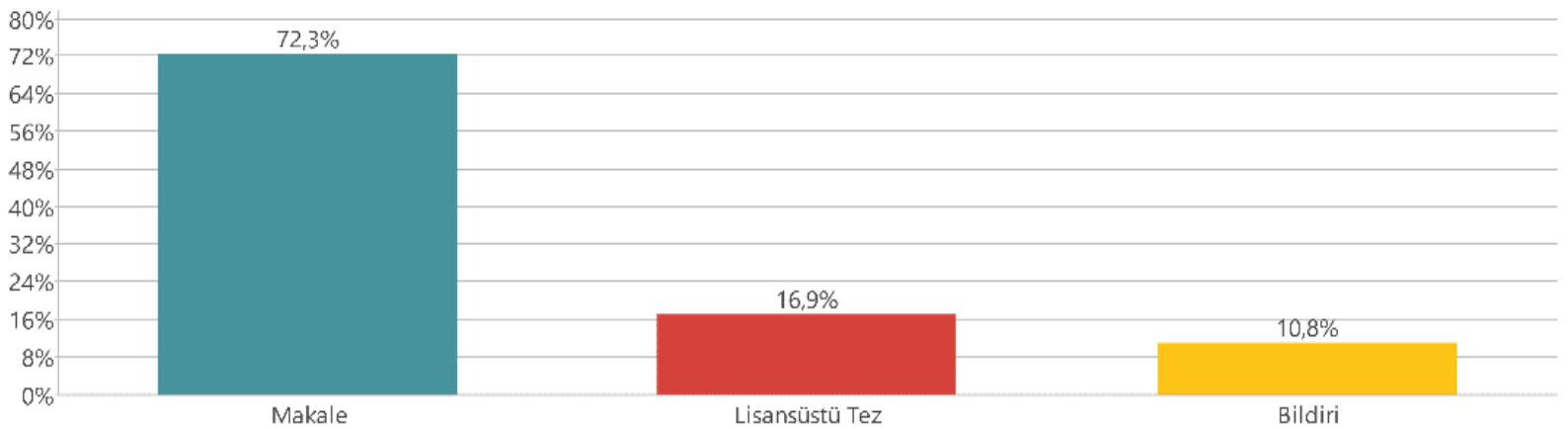

Şekil 2'ye göre belirtilen yıllarda yönetim ve örgütsel davranış alanındaki ölçek geliştirme çalışmalarının en yüksek kodlama ile $(\% 72,3)$ makalelerin olduğu; bunu sırasıyla $(\% 16,9)$ lisansüstü tezlerin ve $(\% 10,8)$ ile bildirilerin izlediği görülmüştür. Elde edilen bu sonuç, 2000-2019 yılları arasında yapılan ölçek geliştirme çalışmalarının en fazla makale olarak yayınlandığını göstermektedir.

4.3. Yönetim ve Örgütsel Davranış Yazınındaki Ölçek Geliştirme Çalışmalarında Uygulanan Ölçek Geliştirme Adımları

2000-2019 yılları arasında YÖK tez merkezinde ve ulusal veri tabanlarında taranan yönetim ve örgütsel davranış yazınındaki ölçek geliştirme çalışmaları araştırmacılar tarafından belirlenen ölçütler 
doğrultusunda incelenmiş ve ölçek geliştirme adımları doğrultusunda kodlanmıştır. Bu çerçevede, ölçek geliştirme adımları ana temalar ve buna bağlı çeşitli alt kodlar kapsamında ele alınmıştır. Tablo 2'de ana ve alt kodlar bağlamında mevcut ölçek geliştirme çalışmalarında izlenen adımlar verilmektedir.

Tablo 2. 2000-2019 Yılları Arasında Ulusal Düzeyde Yayınlanan Ölçek Geliştirme Çalışmalarında İzlenen Adımları Gösteren Yoğunluk Tablosu

\begin{tabular}{|c|c|c|c|c|}
\hline \multicolumn{2}{|c|}{ Kod Sistemi } & Lisansüstü Tezler & Bildiriler & makaleler \\
\hline \multirow{2}{*}{\multicolumn{5}{|c|}{ 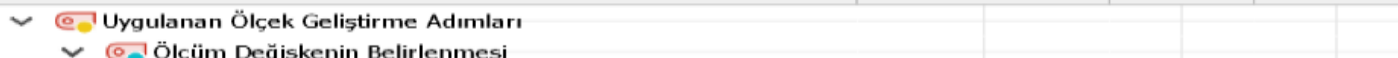 }} \\
\hline & & & & \\
\hline \multicolumn{5}{|c|}{ egavramsallastırma } \\
\hline \multicolumn{5}{|c|}{ ๑ kuramsal temel } \\
\hline \multicolumn{5}{|c|}{$\checkmark$ C. Madde havuzunun oluşturulması } \\
\hline \multicolumn{5}{|c|}{$\odot$ literatür taraması } \\
\hline \multicolumn{5}{|c|}{ ๑ uzman görüşü } \\
\hline \multicolumn{5}{|c|}{ ๑๐ülakat } \\
\hline \multicolumn{5}{|c|}{ ¿ tümevarım } \\
\hline \multicolumn{5}{|c|}{ ¿ tümdengelim } \\
\hline \multicolumn{5}{|c|}{ Delphi tekniği } \\
\hline \multicolumn{5}{|c|}{$\odot$ açık uçlu sorular } \\
\hline \multicolumn{5}{|c|}{$\odot$ nitel araştırma } \\
\hline \multicolumn{5}{|c|}{ ¿ odak grup görüşmesi } \\
\hline \multicolumn{5}{|c|}{ ๑ var olan ölçeklerin taranması } \\
\hline \multicolumn{5}{|c|}{$\checkmark$ ¿ Başlangıç madde havuzunun değerlendirilmesi } \\
\hline \multicolumn{5}{|c|}{ ๑ Görünüm geşerliliği } \\
\hline \multicolumn{5}{|c|}{ ๑๐apsam Geçerliliği } \\
\hline \multicolumn{5}{|c|}{$\checkmark$ ¿ Ölçme yöntemi } \\
\hline \multicolumn{5}{|c|}{ ๑ フ^li likert } \\
\hline & 5'll Likert & $\square$ & . & - \\
\hline & ๔ Pilot Uygulama & - & - & $=$ \\
\hline & @- Pilot Arasturma sonrası uzman değerlendirmesi & $\cdot$ & & . \\
\hline$\sim$ & Güvenilirlik analizleri & $=$ & & \\
\hline & $\checkmark$ iç Tutarlılık & . & & \\
\hline & C Yarıya bölme & 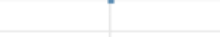 & & \\
\hline & Composite Reliability & & & 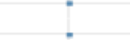 \\
\hline & Benzeyen Bileşik Güvenillirlik (AVE) & . & & \\
\hline & ¿ boyutlararası korelasyon & $=$ & & - \\
\hline & C Madde-toplam puan & $=$ & - & 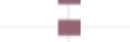 \\
\hline & Cronba Alpha & $\square$ & - & $\bar{\square}$ \\
\hline & Paralel-Form & & . &. \\
\hline & ¿-Test-Tekrar & & . & $=$ \\
\hline$\checkmark$ & Geçerlilik analizleri & & & \\
\hline & $\checkmark$ Corumsal Geçerlilik & & & \\
\hline & ๑๑ Görünüş Geçerliliği & & & \\
\hline & Kapsam Geçerlilik Indeksi & 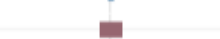 & . & . \\
\hline & $\checkmark$ Kriter Geçerliliği & 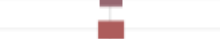 & 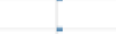 & . \\
\hline & Es Zaman Geçerliliği & & . & 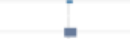 \\
\hline & $\odot$ Yordama geçerliliği & $=$ & & 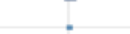 \\
\hline & $\checkmark \odot_{\odot}$ Yapı Geçerliliği & & & \\
\hline & •• Benzeşim geçerliliği & $=$ & . & 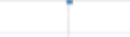 \\
\hline & $\odot$ İkinci Düzey DFA & . & & . \\
\hline & —Acıklayıcı Faktör Analizi & $\square$ & $=$ & $\square$ \\
\hline & $\odot$ Doğrulayıcı Faktör Analizi & $\overline{1}$ & - & 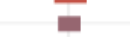 \\
\hline & 을 Nihai ölçek maddelerinin belirlenmesi & $\overline{-}$ & & $=$ \\
\hline
\end{tabular}

Tablo 2'de elde edilen sonuçlar, 2000-2019 yılları arasında ulusal düzeyde yayınlanan tez, makale ve bildiri kapsamındaki ölçek geliştirme çalışmalarında araştırmacılar tarafından izlenen ölçek geliştirme adımlarının yoğunluğunu göstermektedir. Buna göre; ölçek geliştirme çalışmalarının ilk aşaması olan ölçüm değişkenin belirlenmesi kapsamında; ölçülmek istenen kavramın açık bir şekilde tanımlandığı ancak kavramın dayandığı kuramsal temele nadiren değinildiği görülmektedir. İkinci aşamayı temsil eden başlangıç madde havuzunun oluşturulması çerçevesinde ise sıklıkla literatür taraması, uzman görüşü ve mülakat süreçlerinin yerine getirildiği ve aynı zamanda bu madde havuzunun değerlendirilmesinde kapsam geçerliliğine dikkat edildiği sonucu elde edilmiştir. Ölçme yöntemi olarak daha çok 5'li Likert yöntemi kullanıldığı ve genellikle pilot araştırma yapıldığı belirlenmiştir. Pilot araştırma sonrası uzman değerlendirmesinin ise uygulanmadığı görülmüştür. Bununla birlikte diğer bir aşama olan güvenilirlik analizleri kapsamında daha çok Cronbach's Alpha katsayısının, madde toplam puanının ve boyutlararası korelasyon değerlerinin hesaplandığı, kısmen 
test-tekrar yönteminin uygulandığı; yarıya bölme ve paralel form yöntemlerinin ise nadiren uygulandığı bulgusuna ulaşımıştır. Geçerlilik çalışmaları aşamasında ise kapsam geçerliliğin ve yordama geçerliğinin sağlandığı; yapısal geçerlilik çerçevesinde ise yaygın olarak açıklayıcı ve doğrulayıcı faktör analizlerinin kullanıldığı görülmüştür. Son aşama olan nihai ölçek maddelerinin sunulması adımında, tez çalışmalarında maddelere yer verildiği ancak bildiri ve makalelerde ise ölçek maddelerinin kısmen sunulduğu belirlenmiştir.

Mevcut ölçek geliştirme çalışmaları DeVellis (2003), Cabrera-Nguyen (2010), Boateng vd. (2018) ve Carpenter (2018) tarafından ele alınan ölçek geliştirme adımları kapsamında değerlendirildikten sonra izlenmesi gereken ana ve alt metodolojik aşamalar bir model dâhilinde gösterilmiştir. Şekil 3'de ölçek geliştirme çalışmalarında izlenmesi gereken ilkeler özetlenmektedir.

Şekil 3. Ölçek Geliştirme Çalışmalarında İzlenmesi Gereken Aşamalar

\section{Hiyerarşik Kod-Alt kod Modeli}

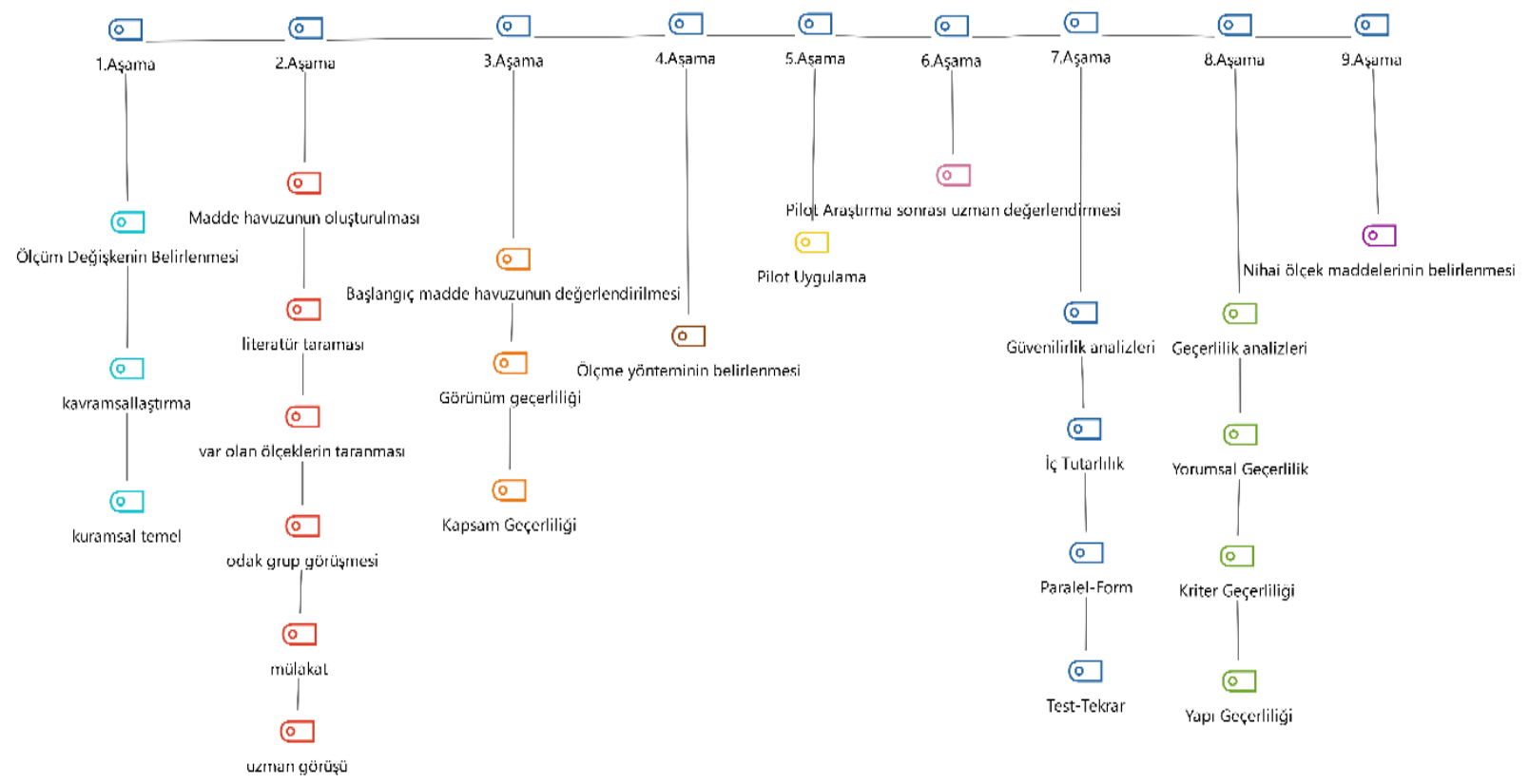

\section{Sonuç}

Sosyal bilimler alanında bireylerin tutum, davranış, algılama, kişilik gibi özelliklerini ölçmek amacıyla ölçek adı verilen ölçüm araçları kullanılmaktadır. Ilgili alan yazında bireysel farklııkların temelini oluşturan bu unsurların ölçülmesinde var olan ölçekler kullanılmaktadır. Ancak bazen araştırmacılar mevcut ölçeklerin yetersiz olduğuna kanaat getirerek, ölçmek istedikleri değişkenlere yönelik ölçek geliştirme çabası içerisine girmektedirler. Ölçek geliştirme, ölçülmesi planlanan değişkene ilişkin derin bir alan uzmanlık ve metodoloji bilgisi gerektiren, zahmetli ve uzun soluklu bir süreçtir. Bu sürecin başarısı ise ölçek geliştirme ilkelerinin tüm aşamalarının titizlikle uygulanmasına dayanmaktadır. Alan yazında araştırmacılar tarafından ölçek geliştirme çalışmalarında dikkate alınması gereken adımlar, uygulanması gereken istatistiksel teknikler ve kullanılması gereken metotlar geniş bir çerçevede sunulmuştur. Bu çalışmada, araştırmacıların ölçek geliştirme çalışmalarında önerdiği kriterler kapsamında Türkiye'de ulusal veri tabanlarında yer alan lisansüstü tezler, makale ve bildirilerin içerik analiz yöntemiyle incelenmesi ve mevcut durumun ele alınması amaçlanmıştır. Bununla birlikte ölçek geliştirme çalışmalarında izlenmesi gereken aşamalar bir model dâhilinde sunularak, alan yazına katkı sağlanmaya çalışılmışır. Bu amaç kapsamında 2000-2019 yılları arasında ulusal veri tabanlarında taranan yönetim ve organizasyon ile örgütsel davranış alanındaki tez, makale ve bildiri türünde 65 adet bilimsel çalışma ölçek geliştirme adımları kapsamında analiz edilmiştir. 
Elde edilen bulgulara göre, ölçek geliştirme çalışmalarının ilk aşaması olan ölçüm değişkenin belirlenmesi adımında değişkenlerin kuramsal temellerine nadiren değinildiği, başlangıç madde havuzunun hazırlanmasında ise yaygın olarak var olan ölçeklerin irdelendiği, alan yazın taraması yapıldığı, uzman görüşüne yer verildiği ve çoğunda mülakat yönteminin kullanıldığı görülmektedir. Bununla birlikte, incelenen çalışmalarda pilot uygulamanın yerine getirildiği ancak bu uygulama sonrasında tekrar bir uzman görüşü değerlendirmesinin yapılmadığı sonucuna ulaşılmıştır. Diğer taraftan güvenilirlik ve geçerlilik analizlerinin neredeyse tüm çalışmalarda uygulandığı ancak tüm aşamalarının tamamıyla yerine getirilmediği görülmüştür. Diğer bir ifadeyle, güvenilirlik analizleri kapsamında Cronbach's alpha katsayısının, madde toplam puanının ve boyutlararası korelasyon değerlerinin hesaplandığı, ancak test-tekrar ve paralel form yönteminin nadiren uygulandığı belirlenmiştir. Ayrıca geçerlilik analizleri çerçevesinde ise açıklayıcı faktör ve doğrulayıcı faktör analizi çalışmaların önemli ölçüde kullanıldığı görülmüştür. Sonuç olarak, incelenen çalışmalarda alan yazındaki ölçek geliştirme adımlarının kısmen uygulandığı görülmekle birlikte nitel ve nicel yöntemlerin bir arada kullanıldığı çalışma sayısının azlığı dikkat çekmektedir. Özellikle nitel araştırma kapsamında tümevarım yönteminin kullanılarak başlangıç madde havuzunun oluşturulduğu çalışma sayısı kısıtıdır. Diğer taraftan geliştirilen ölçek maddelerinin incelenen çalışmalarda nadiren paylaşıımasının ilgili alan yazına olan katkısını azaltması mümkündür. Bu doğrultuda, ölçek geliştirme çalışması yapmayı planlayan araştırmacılara, ölçek geliştirme sürecinin; ölçüm değişkenin belirlenmesi, başlangıç madde havuzunun oluşturulması, bu madde havuzunun değerlendirilmesi, ölçme yönteminin belirlenmesi, pilot uygulama, pilot araştırma sonrası uzman değerlendirmesi, güvenilirlik analizleri, geçerlilik analizleri, ölçeğe nihai halinin verilmesi olmak üzere dokuz aşamalı bir süreç çerçevesinde yerine getirilmesi önerilebilir. Diğer taraftan yönetim-organizasyon ve örgütsel davranış yazınından ziyade sosyal bilimler alanındaki tüm ölçek geliştirme çalışmalarının incelenmesiyle, sosyal bilimler alanına yönelik alan yazına katkı sağlayacak çalışmaların yapılması önerilebilir.

\section{Beyan ve Açıklamalar (Disclosure Statements)}

1. Bu çalışmanın yazarları, araştırma ve yayın etiği ilkelerine uyduklarını kabul etmektedirler (The authors of this article are admitted that they complied with the principles of research and publication ethics).

2. Yazarlar tarafından herhangi bir çıkar çatışması beyan edilmemiştir (No potential conflict of interest was reported by the authors).

3. Bu çalışma, intihal tarama programı kullanılarak intihal taramasından geçirilmiştir (This article was screened for potential plagiarism using a plagiarism screening program).

\section{Kaynaklar}

Boateng, G. O., Neilands, T. B., Frongillo, E. A., Melgar-Quiñonez, H. R., \& Young, S. L. (2018). Best practices for developing and validating scales for health, social, and behavioral research: A primer. Frontiers in Public Health, 6(149), 1-18.

Bolarinwa, O. A. (2015). Principles and methods of validity and reliability testing of questionnaires used in social and health science researches. Nigerian Postgraduate Medical Journal, 22(4), 195-201.

Cabrera-Nguyen, P. (2010). Author guidelines for reporting scale development and validation results in the journal of the society for social work and research. Journal of the Society for Social Work and Research, 1(2), 99-103.

Carpenter, S. (2018). Ten steps in scale development and reporting: A guide for researchers. Communication Methods and Measures, 12(1), 25-44.

Çüm, S., \& Koç, N. (2013). Türkiye'de psikoloji ve eğitim bilimleri dergilerinde yayımlanan ölçek geliştirme ve uyarlama çalışmalarının incelenmesi. Eğitim Bilimleri ve Uygulama, 12(24), 115-135.

DeVellis, R. F. (2003). Scale development: Theory and applications (2nd ed.). Sage Publications.

Dirlik, E. M. (2014). Ölçek geliştirme konulu doktora tezlerinin test ve ölçek geliştirme standartlarına uygunluğunun incelenmesi. Eğitimde ve Psikolojide Ölçme ve Değerlendirme Dergisi, 5(2), 62-78.

Karakoç, F. Y., \& Dönmez, L. (2014). Ölçek geliştirme çalışmalarında temel ilkeler. Tıp Eğitimi Dünyası, 13(40), 39-49. 
Kanten, P., Gümüştekin, G., \& Durmaz, M.G. (2018). Öfke yönetimini etkileyen öncüller: hemşireler üzerinde nitel bir araştırma. 6.Örgütsel Davranış Kongresi Bildiriler Kitabı, 2-3 Kasım, Isparta, 940-952.

Morgado, F. F. R., Meireles, J. F. F., Neves, C. M., Amaral, A. C. S., \& Ferreira, M. E. C. (2017). Scale development: Ten main limitations and recommendations to improve future research practices. Psicologia: Reflexão e Crítica, 30(3), $1-20$.

Sığrı, Ü. (2018). Nitel araştırma yöntemleri (1. Baskı). İstanbul: Beta Basım Yayım Dağıtım.

Şahin, M. G., \& Öztürk, N. B. (2018). Eğitim alanında ölçek geliştirme süreci: Bir içerik analizi çalışması. Kastamonu Üniversitesi Kastamonu Eğitim Dergisi, 26(1), 191-199.

Tavşancıl, E., Güler, G., \& Ayan, C. (2014). 2002-2012 yılları arasında Türkiye'de geliştirilen bazı tutum ölçeği geliştirme çalışmalarının ölçek geliştirme süreci açısından incelenmesi. IV. Ulusal Eğitimde ve Psikolojide Ölçme ve Değerlendirme Kongresi (Uluslararası Katılımlı), Hacettepe Üniversitesi, Ankara.

Tay, L., \& Jebb, A. T. (2017). Scale development. The SAGE Encyclopedia of Industrial and Organizational Psychology, 1 5.

Uyanık, G.K., Güler, N., Teker, G. T., \& Demir, S. (2017). Türkiye'de eğitim alanında yayımlanan ölçek geliştirme çalışmalarının uygunluğunun çok yüzeyli rasch modeli ile incelenmesi. Eğitimde ve Psikolojide Ölçme ve Değerlendirme Dergisi, 8(2), 183-199.

Yeşilyurt, S., \& Çapraz, C. (2018). A road map for the content validity used in scale development studies. Erzincan Üniversitesi Eğitim Fakültesi Dergisi, 20(1), 251-264.

Yurdabakan, ì., \& Çüm, S. (2017). Scale development in behavioral sciences (based on exploratory factor analysis). Turkish Journal of Family Medicine and Primary Care, 11(2), 108-126.

Zhou, Y. (2019). A mixed methods model of scale development and validation analysis. Measurement: Interdisciplinary Research and Perspectives, 17(1), 38-47. 